\title{
Preparatory IT practices and skills of transition Business students (1997)
}

\author{
Andrew Stein \\ Annemieke Craig \\ Angela Scollary \\ Victoria University of Technology, Melbourne
}

Transition students come to universities with a need to be information competent but typically lack basic information literacy skills. This research report presents the findings of a study of the IT profile of transition students within the Faculty of Business at Victoria University of Technology. Two definitions were used to categorise information technology usage. General IT practices looked at the availability of IT to the student, including home and work access, usage at home, previous information systems courses studied and computer competency. Specific IT skills referred to the use of business information technology, including word processing, spreadsheet and database as well as Internet, email and multimedia packages. Major findings showed that home access to a computer has peaked, access to a work related computer is increasing, and gender and student geography seem to have an effect upon the students IT practices and skills. Use of the Internet and multimedia is increasing in transition students.

\section{Introduction}

- In November of each year the Department of Information Systems, at Victoria University of Technology assesses subject and course content and debates dropping tutorial instruction in word processing from the core Computer Applications subject in the Bachelor of Business. This decision had been under consideration for two years and the knowledge that $70 \%$ of entrance students had previously used word processing had been a convincing argument. Important contra arguments included uncertainty about the level of word processing knowledge of the entrance students and that $30 \%$ had not used a word processor at all. 
- In 1996 the Department was asked to provide Internet sessions to Year 10 students from a large feeder school. In preparation for these sessions it was discovered that this school had its own home page and a room of computers with Internet access. During the sessions it was evident that staff and a majority of students were familiar with the Internet and its operation.

- Computing is delivered in many courses at Vic Uni. There are formal computing courses and extensive use of computing in non-computing departments. Several non-computing areas have developed extensive web sites and as part of their curricula have students developing WWW authoring skills by creating home pages.

In each of the above examples we see the potential for curriculum design to be impacted by technology. With the rapid change in technology, university Information Systems departments need to obey two masters; the changing external information systems environment, and the changing needs of their students. This paper seeks to add to the dialogue looking at the changing technology imperative in universities by surveying the information technology (IT) skills of university entrance students.

\section{Information competency, education and employee skills}

A review of the Australian economy and labour market has shown that patterns of employment and skill needs are affected by demographic, educational, domestic, economic and political forces. The Department of Education, Employment and Training (DEET) Workforce reports (1991, 1995) both chart the projected employment growth and changes expected as we near the year 2000. Two of the major business imperatives identified in the 1995 report were the globalisation of the Australian industrial landscape and the convergence of the communication and computer technologies. Karpin (1995) emphasised this globalisation of the Australian economy and suggested that:

Australian enterprises will deliver such world competitive products and services only through enhanced productivity of their people and technology ....There is no sign these competitive pressures will decrease, in fact they will increase as more countries industrialise and trade barriers fall.

The NBEET report (1995b) identified the convergence of communications and computers as giving rise to a plethora of new job skills. These new job skills impact upon all levels of the organisation from the blue collar worker up into the management suite. The general skills as required by the labour 
force included: keyboard skills; information formatting skills; 'intelligent' use of computer communications facilities; library and information retrieval skills; and data analysis skills. The report went further and highlighted new skills in the emerging communications industries: understanding of organisational information requirements; understanding client/server architectures; knowledge of international telecommunication standards; document management in a paperless environment; and translation of business cases into information technology design. The term information competency (NBEET 1995a) seeks to name the skills needed to operate within the business world of today. It covers the technology competence, information research skills and the development of higher order thinking skills. The computer is a major tool in developing this competency. Information literacy is one component of information competency and is defined as the ability:

...to use information and information technologies effectively to find, select, and use information to create knowledge and insight...

The importance of the concept of information competence is displayed in recommendation 12 of the NBEET (1995b) report;

Standards of information competence to be clearly identified within the key competency of 'using technology' and where these are not achieved to a Year 12 level of learning, they should be built into the Australian Vocational Training System or higher qualifications.

Government bodies and the business world are recognising the need for new and enhanced information processing and information technology skills. Schools are modelling curricula to adapt to the changing needs of their students. An extensive study by Sherwood (1993) found that wide variations exist between computer use and access within secondary schools Australia wide. The major impediment to computer use was "too few computers for students needing access". Transition students come to universities with a need to be information competent but typically lack basic information literacy skills through circumstances at their at secondary schools (Curriculum Corporation, 1995; NECF, 1991). University departments must recognise this problem and be able to measure the information competency of transition students.

Increased funding by the government has seen an explosion in the number of places for local students along with an increase in the number of students from overseas. In 1983 there were 348,500 students enrolled in Australian Universities and this has now soared to 622,048 in 1995 (Maslen 1995). Professor Tinto (1995), an international expert on first year university 
students, has argued that it is critical for Universities to collect and analyse both quantitative and qualitative data about students. He considers that this will enable a university to learn more about students' needs and thus be able to more effectively address them. This paper looks at the transition student with an emphasis on the IT skills that the incoming student possesses. Many studies (Sherwood 1993, Oliver 1993, McCormick 1992, Birnbaum 1990, Andersen 1991, Martinez 1986, Atweh 1989) both in Australia and overseas have charted the IT skills of transition students. These studies all yielded results that showed that IT skills of transition students had increased significantly in recent years and it is anticipated IT skills of students will always be escalating, matching the general trend within society.

\section{Research questions}

The purpose of this study was to provide the IT profile of the transition student within the Faculty of Business at Victoria University of Technology. The information relating to IT skills will enable us to plan where to commence our own IT/IS teaching to build on the existing skills base. Two definitions are used to categorise information technology usage of students. General IT practices look at the availability of IT to the student. This included home and work access, usage at home, previous information systems courses studied and computer competency. Specific IT applications referred to the use of business information technology. This included the familiar word processing, spreadsheet and database as well as the emerging Internet, email and multimedia packages. The general research question for this study involves ascertaining the IT skills/practices that commencing students bring to the University. More specific research questions were:

RQ1. Are transition student IT practices changing with time?

RQ2. Are transition student IT skills changing with time?

RQ3. Are transition student IT practices/skills correlated with educational and social background?

\section{Methodology}

Data was gathered in this study through the administration of a survey to all first year commencing business undergraduate students on all of the five undergraduate campuses of the university. From a possible 860 students, 566 students completed the survey giving a response rate of $70 \%$. The nature of the questionnaire is described below together with a sample question. 


\section{Students}

Students were surveyed in either the orientation week or the first week of their first semester at Vic Uni. Questionnaires were distributed and collected in lectures. Distribution through these early lectures was chosen to maximise the participation by students at the critical interface of their transition into tertiary studies.

\section{The questionnaire}

The questionnaire comprised four parts. The first section gathered information concerning each student. This included: campus; study mode; student/parent birthplace; languages spoken at home; family history of participation in higher education and course studied. The second section gathered information on the students' immediate past educational experiences. The student selected options by tick box. The third section focused on the students selection of course and university.

The last section gathered information on computer related issues and IT skill levels. This included: home use of computer; student self-perception of computer competency and keyboard skills; VCE Information Technology based subjects undertaken; previous experience in the use of computers and IT packages that the students had used. The question relating to their use of IT packages required the student to select their use of packages from None, 2 hours and $>2$ hours. This data collection was felt to be more objective rather than asking for the students self-perception of their knowledge of packages.

For each question students responded to either preselected options or a 5 point Likert scale together with an option for additional comment. Questions $1 \& 2$ will be tested by time series comparative frequencies and question 3 will be analysed by cross-tabulation frequency.

\section{Sample question}

On average how many hours per week do you spend using each of the following.

\begin{tabular}{|c|c|c|c|c|c|c|}
\hline & None & $<2$ & $2+$ & & one & $<2$ \\
\hline 46. Word Processing & $\square$ & ] & a & 52. Spreadsheets & a & \\
\hline 47. Database & a & ב & a & 53. Programming & 口 & [ \\
\hline 48. Games & ] & ב & ] & 54. Modem & a & \\
\hline 49. Internet & a & ב & a & 55. Windows & ב & \\
\hline 50. Laptops & ] & ב & a & 56. Graphics & ב & \\
\hline 51. Email & ם & ב & a & 57. CD-Rom & $\square$ & \\
\hline
\end{tabular}




\section{Results}

\section{Assumption Testing}

The large sample size $(\mathrm{N}=566)$ gave support to the assumption that the distribution was a normal one. Investigation by Histogram, Boxplot, Normal Probability Plots and Detrended Normal Plots further supported the assumption of normality.

\section{Demography}

The majority of students (85\%) were located on the two largest campuses of the university, Footscray and St Albans. The remaining 15\% were located on the Melton campus. The proportion of female students (47\%) is slightly lower than the proportion of females in the first year undergraduate population as a whole (50\%). Students born overseas accounted for $34 \%$ of the cohort with higher proportions coming from families whose parents were overseas born (mother) $65 \%$ and (father) $70 \%$. These figures should be considered together with the number of students who speak a language other than English at home (56\%). Students who completed Year 12 in 1996 accounted for $61 \%$ of the cohort with $10 \%$ being ex-TAFE. This breakdown is in line with faculty projections of TAFE articulators forming a substantial section of commencing students. This also implied students commence with a variety of IT skills developed in TAFE.

\section{Student IT practices: Computer access}

The PC was released in 1983 and the home market has always been predicted to escalate to become all pervading. A high proportion of the student cohort (86\%) had access to a home PC, slightly more than the 1995 result of $76 \%$ (Stein, Craig \& Scollary, 1997). This high level of home access gives rise to questions of expected standards of assignments and access to software for University based assignments. At another level however, we see a gap opening up between students who have home computers and those who do not. This gap has the potential to become significant when we consider the ramifications of the Internet and information access.

\section{Student IT practices: Computer competency and confidence}

The five elements of the competency scale were combined into three levels; low competency, average competency, and high competency. The cohort indicated that $26 \%$ felt they were of low competency with $50 \%$ average competency and $24 \%$ having high levels of competency. This result when compared to previous studies by Stein (1996) and Oliver (1991) showed the expected increasing levels of competency. 


\begin{tabular}{|l|c|c|c|c|}
\hline & 1997 & 1996 & $\begin{array}{c}1995 \\
\text { (Stein et al 1996) }\end{array}$ & Oliver \\
\hline & cohort & cohort & cohort* $^{*}$ & $1991^{* *}$ \\
\hline Low Competency & 26 & 49 & 48 & 45 \\
\hline Average Competency & 50 & 37 & 30 & 40 \\
\hline High Competency & 24 & 10 & 22 & 15 \\
\hline
\end{tabular}

Table 1: Computer competency \% $(\mathrm{N}=566)$

Note: * adapted from 7 point Likert to 5 point Likert.(Stein et al, 1996) ** averaged from Oliver's 4 measures of computer competence.

\begin{tabular}{|l|c|cc|cc|}
\hline & 1997 & \multicolumn{2}{|c|}{1997} & \multicolumn{2}{c|}{1997} \\
\hline & cohort & male female & $\begin{array}{c}\text { West } \\
\text { School }\end{array}$ & $\begin{array}{c}\text { Other } \\
\text { School }\end{array}$ \\
\hline Low Competency & 26 & 22 & 30 & 28 & 25 \\
\hline Average Competency & 50 & 46 & 52 & 50 & 50 \\
\hline High Competency & 24 & 31 & 15 & 22 & 25 \\
\hline & & \multicolumn{2}{|c|}{$\begin{array}{l}\text { t-test (.000) at } \\
\mathrm{p}=.681\end{array}$} & $\begin{array}{l}\text { t-test (.685) at } \\
\mathrm{p}=.271\end{array}$ \\
\hline
\end{tabular}

Table 2: Computer competency by gender and westernality \% ( $\mathrm{N}=566)$

There is a significant gender difference $(t<.05)$ in the student self perception of computer competency. There is no significant geographic difference $(t=.685)$ in the student self perception of computer competency.

\begin{tabular}{|l|c|cc|cc|}
\hline & 1997 & \multicolumn{2}{|c|}{1997} & \multicolumn{2}{|c|}{1997} \\
\hline & cohort & male female & $\begin{array}{c}\text { West } \begin{array}{c}\text { Other } \\
\text { School }\end{array} \\
\text { School }\end{array}$ \\
\hline Low Confidence & 24 & 19 & 29 & 23 & 24 \\
\hline Average Competency & 40 & 37 & 43 & 41 & 40 \\
\hline High Confidence & 35 & 44 & 27 & 35 & 35 \\
\hline & & \multicolumn{2}{|l|}{$\begin{array}{l}\text { t-test }(.000) \\
\mathrm{p}=.099\end{array}$} & $\begin{array}{l}\text { t-test }(.292) \text { at } \\
\mathrm{p}=.428\end{array}$ \\
\hline
\end{tabular}

Table 3: Computer confidence by gender and westernality \% $(\mathrm{N}=566)$

There is a significant gender difference $(\mathrm{t}<.05)$ in the student self perception of computer confidence. There is no significant geographic difference $(t=.292)$ in the student self perception of computer confidence. 


\section{Student IT practices: Computer background}

The students were asked to rate their use of a computer in secondary school, place of employment and home. These results are displayed in Table 4.

\begin{tabular}{|l|c|c|c|c|c|c|}
\hline Background & $\begin{array}{c}\text { Yes } \\
\text { (used) } \\
\text { All } \\
\text { Studs }\end{array}$ & $\begin{array}{c}\text { Yes } \\
97 \\
\text { West } \\
\text { Subs }\end{array}$ & $\begin{array}{c}\text { Yes } \\
97 \\
\text { Ex } \\
\text { Y12 }\end{array}$ & $\begin{array}{c}\text { Yes } \\
97 \\
\text { Ex } \\
\text { Tafe }\end{array}$ & $\begin{array}{c}\text { Yes } \\
97 \\
\text { Male }\end{array}$ & $\begin{array}{c}\text { Yes } \\
\text { Female } \\
\end{array}$ \\
\hline Yrs 7-10 & 76 & 82 & 86 & 87 & 75 & 78 \\
\hline VCE Information P \& M Yr12 & 19 & 21 & 26 & na & 18 & 20 \\
\hline VCE Information Tech Yr11 & 38 & 47 & 44 & na & 35 & 41 \\
\hline VCE Information Sys Yr12 & 8 & 13 & 10 & na & 13 & 4 \\
\hline VCE Info Tech in Soc Yr 12 & 4 & 4 & 4 & na & 4 & 3 \\
\hline Computer at work & 50 & 45 & 46 & 57 & 53 & 47 \\
\hline Computer at home & 86 & 88 & 89 & 87 & 86 & 87 \\
\hline Home use of Internet & 23 & 17 & 22 & 28 & 26 & 19 \\
\hline WIN95 & 52 & 50 & 50 & 54 & 53 & 48 \\
\hline
\end{tabular}

Table 4: Computer background \% (N=566)

The use of the home computer contrasted to Oliver (1991) where 56\% of students replied use of home computers and 32\% reported use of school computers. The trend showed that students are indicating high levels of computer use both at home and at school. This would be in line with expectations. Use of a computer in a work environment introduces a new element in the computer experience of the student.

This feature raises questions exploring the link between the IT skills developed in work situations and the extent to which these will have to be accounted for in course design. A general economic trend is for an increase in part time employment by students and if students are therefore developing organisational computing skills how are we to accommodate them?

Several trends are evident in Table 4 and 5 . There was a marked decrease in the number of Yr 12 students taking the IT based subjects in VCE. This trend is important as these subjects develop information systems skills revisited in many university based subjects. This goes against 1996 VTAC figures where the subject Information Processing and Management had a 
12\% increase in enrolment from 1994 to 1996 (Houghton 1996, Ainley 1994).

\begin{tabular}{|l|c|c|}
\hline Background & $\begin{array}{c}\text { 1996 Year12 } \\
\text { cohort } \mathrm{n}=345\end{array}$ & $\begin{array}{c}\text { 1995 Year12 } \\
\text { cohort } \mathrm{n}=491\end{array}$ \\
\hline Yrs 7-10 & 76 & 79 \\
\hline VCE Information Processing \& Man & 19 & 45 \\
\hline VCE Information Technology & 38 & 39 \\
\hline VCE Information Systems & 8 & 13 \\
\hline VCE Information Tech in Society & 4 & 4 \\
\hline Computer at work & 50 & 42 \\
\hline Computer at home & 86 & 80 \\
\hline Home use of internet & 23 & na \\
\hline Win95 & 52 & na \\
\hline
\end{tabular}

Table 5: Comparison of computer background by Year 12 completion \% $(\mathrm{N}=345)$

Internet usage at home shows both a gender (male 26\% female 19\%) and geographic (west $17 \%$ other 22\%) gap opening up between student populations.

\begin{tabular}{|l|c|c|c|c|c|c|c|}
\hline & None & $<2$ & $2+$ & $\begin{array}{c}1997 \\
\text { Combined } \\
<2 \& 2+\end{array}$ & $\begin{array}{c}1996 \text { cohort } \\
\text { Stein et al, } \\
1997\end{array}$ & $\begin{array}{c}1995 \text { cohort } \\
\text { Stein et al, } \\
1996\end{array}$ & $\begin{array}{c}1993 \\
\text { Sherwood, } \\
1993\end{array}$ \\
\hline Word Proc & 21 & 42 & 36 & 78 & 74 & 87 & 90 \\
\hline Spreadsheet & 51 & 40 & 8 & 48 & 52 & 68 & na \\
\hline DataBase & 65 & 28 & 6 & 34 & 33 & 48 & 55 \\
\hline Windows & 25 & 36 & 38 & 74 & 73 & 76 & na \\
\hline Internet & 72 & 15 & 12 & 27 & 22 & 7 & na \\
\hline Graphics & 66 & 23 & 10 & 33 & 33 & na & 62 \\
\hline Games & 35 & 35 & 30 & 65 & 57 & 65 & 69 \\
\hline Email & 75 & 17 & 7 & 25 & 28 & na & 23 \\
\hline Program'g & 79 & 16 & 4 & 20 & 19 & 13 & 33 (logo, \\
\hline Laptops & 81 & 11 & 7 & 18 & 14 & na & na \\
\hline Multi-media & 69 & 18 & 12 & 30 & 31 & na & 17 \\
\hline
\end{tabular}

Table 6: Use of IT (\%) applications $(\mathrm{N}=566)$ 


\section{Student IT skills: IT applications}

Students were then asked to report their use of common IT applications with the hours of use as reported in Table 6. The 1995 and 1996 survey cohorts are included. Windows and the common packages all showed high levels of use.

The Internet at $22 \%$ compared with $7 \%$ in the previous survey. The "big 4" were in common usage with database being the least used. Games were used extensively with the email and multimedia providing baseline data for future analysis.

\begin{tabular}{|c|c|c|c|c|c|}
\hline & \multirow{2}{*}{$\begin{array}{c}1997 \\
\text { Used IT } \\
\text { Combined } \\
<2 \& 2+\text { hrs } \\
\end{array}$} & \multicolumn{2}{|c|}{$\begin{array}{l}1997 \\
\text { Used IT by Gender } \\
<2 \& 2+\text { hrs }\end{array}$} & \multicolumn{2}{|c|}{$\begin{array}{c}1997 \\
\text { Used IT by Westernality } \\
<2 \& 2+\text { hrs }\end{array}$} \\
\hline & & Male\% & Female $\%$ & $\begin{array}{c}\text { West } \\
\text { School \% } \\
\end{array}$ & $\begin{array}{c}\text { Other School } \\
\%\end{array}$ \\
\hline Word Proc & 78 & 78 & 81 & 83 & 77 \\
\hline Spreadsheets & 48 & 50 & 46 & 52 & 46 \\
\hline DataBase & 34 & 37 & 31 & 36 & 33 \\
\hline Windows & 74 & 75 & 73 & 82 & 71 \\
\hline Internet & 27 & 32 & 20 & 26 & 26 \\
\hline Graphics & 33 & 39 & 27 & 32 & 33 \\
\hline Games & 65 & 71 & 56 & 69 & 61 \\
\hline Email & 25 & 27 & 21 & 23 & 24 \\
\hline Programming & 20 & 22 & 15 & 22 & 19 \\
\hline Laptops & 18 & 21 & 13 & 10 & 20 \\
\hline Multimedia & 30 & 37 & 22 & 32 & 29 \\
\hline
\end{tabular}

Table 7: Use of IT (\%) applications by gender and westernality ( $\mathrm{N}=566)$

\section{Discussion and Conclusion}

RQ1. Are student IT practices changing with time?

Home access seems to have reached a plateau figure of about $86 \%$. The access to a home computer is in line with common perceptions. Use of a work computer is higher for male and ex-TAFE students but even for 1996 Y12 students, figures of $50 \%$ shows this factor to be important. Work access showed students are increasingly coming to universities with organisational computing skill sets. If we accept that more students are 
meshing University workloads with part time work then should University departments take account of this level of IT experience in subject offerings?

The example of the rapid growth of Web technology within organisations could impact upon University departments when this technology is used to deliver student work. Two years ago introducing students to the design and development of Web pages was cutting edge. Today Year $11 \& 12$ students do this work. Today introducing students to the tools that allow Web based electronic commerce to be developed is cutting edge. When will our incoming students tell us about their Web based business they run from home?

RQ2. Are student IT skills changing with time?

For an information systems department providing in-depth IS instruction to students and general IT teaching for business students there are several important findings. The "big 4" applications all compared closely with the 1995 and 1993 surveys. Spreadsheets are now used by about half of incoming students whilst programming is used by about $20 \%$ of students. A possible strategy to find the appropriate level of IT instruction for the commonly used packages would to use refresher or enabling courses for non-users (Word Processing $=22 \%$ ). Increasingly, enabling courses for spreadsheet, database and multimedia/Internet tools may be necessary. Comparison with the 1993 survey shows an increase in the use of email and multimedia tools. A further question to be asked is the use of the latest IT package to deliver the IT principle. Students with enhanced IT skills are often being asked to develop assignment work and then backload to previous versions of software. Students seem to be saying they want the IT/IS principles taught with the latest packages/platforms to enhance their employability. The question of developing the resources to give the students what they want is going to be increasingly more crucial as packages/platforms evolve.

RQ3. Are student IT practices/skills correlated with student educational and social background?

The results of t-tests show there was a significant gender difference in the students self perception of computer competence and confidence. Whilst self-perception is a subjective measure the gender difference could be explained in the enrolment patterns in computer based subjects in higher secondary studies and the increased usage of computers by male transition 
students. This is supported in table 7 where on the eleven IT tools only word processing showed increased usage by female students. There was a substantial gender gap in the usage of IT tools in the games, multi-media and graphics areas. Potentially more important was the gender gap in the use of the internet. Enabling programs may be necessary again to refresh or introduce these IT practices and skills in the transition cohort. It is the policy of University to put resources into assisting disadvantaged cohorts within the student body, it may well be necessary to extend this program into the gender cohort. The use of laptops showed a significant difference between western suburbs and other schools. This could be due to the resource advantage offered by non-western suburbs schools. There are several well documented examples of schools employing laptop technology to give their students the "technological edge". If in fact these students are IT rich then what strategies can we employ to employ to aid the student from the IT poor educational sector? Again, enabling courses specifically targeted for females and western suburbs students in the IT skills areas seems to be justified.

\section{Further research}

Information technology is having an impact both upon our transition students and the subjects and courses we present. Access to the Internet and multimedia developments need to be studied and charted. It is proposed that the study that formed the basis of this paper will be continued in 1998 with revised questionnaire and possible extension into other Universities.

\section{References}

Ainley, J., Robinson, L., Harvey-Beavis, A., Elsworth, G. and Fleming, M. (1994). Subject Choice in Years 11 and 12. Australian Government Publishing Service, Canberra.

Andersen, J. (1991). Information technology- a cross curricula competence for all pupils. Computers and Education, 16(1).

Atweh, B. (1989). Patterns of student access to and use of computers by gender, social class, type of school and geographical location in Queensland schools. Australian Association for Research in Education, Adelaide, November 1989.

Birnbaum, I. (1990). The assessment of IT capability. Journal of Comp Education, Vol. 6. 
Clark, E. (1990). Problems of retention in tertiary education. Education Research \& Perspectives, 17(2).

Curriculum Corporation (1995). As reported in The Australian Financial Review, 3rd. February, 1995.

DEET (1991). Australia's Workforce in the Year 2001 (Workforce 2001). Department of Education Employment and Training, Australian Government Publishing Service, Canberra.

DEET (1995). Australia's Workforce 2005: Jobs in the Future. Department of Education Employment and Training, Australian Government Publishing Service, Canberra

Houghton, J. (1996). 1996 VCE Enrolments: An Initial Report. Research/ Evaluation Unit.

Karpin, D. (1995). Enterprising Nation. Report of the Industry Task Force on Leadership and Management Skills, April 1995.

Martinez, M. (1988). Computer competence: The first national assessment. Office of Educational Progress, Princetown, NJ.

Maslen, Geoff (1995). Enrolments rocket as demand diversifies. Campus News, August 17th; 5: 5 (32).

McCormick, R. (1992). Curriculum development and new information technology. Journal of Information Technology for Teacher Education, 1(1).

NBEET (1995a). Education and Technology Convergence:A survey of technology infrastructure in education and the professional development and support of educators and trainers in information and communication technologies. National Board Employment Education \& Training Commissioned Report No.41, AGPS, January 1995, Canberra.

NBEET (1995b). Converging: Technology, work and learning. National Board Employment Education \& Training, AGPS, November 1995, Canberra.

NECF (1991). National Education and Communications Framework. Unpublished report of Working Party, March, 1992.

Oliver, R. (1992). The perceptions of school leavers towards information technology skills. Australian Educational Computing, May 1993.

Sherwood, C. (1993). A national survey on the integration of computers into schools: Teachers' current practices and experiences (years 1-12). Faculty of Education, Griffith University, Queensland. 
Stein, A., Craig, A and Scollary, A. (1996). In Transition - The profile of commencing business faculty students for 1995. Paper presented at the Second Pacific Rim Conference, Melbourne University, 3-5 July, 1996.

Stein, A., Craig, A. and Scollary, A. (1997). In Transition - The profile of commencing business faculty students for 1995. Unpublished paper, 3-5 July, 1997.

Tinto, V. (1995). Reported in "Helping first year students stay the course". Nexus, 5(15), August 1995, p.3.

Andrew Stein, Annemieke Craig and Angela Scollary are in the Department of Information Systems, Victoria University of Technology, Melbourne, Victoria. Contact address:

andrew=stein @vut.edu.au

PO Box 14428, MCMC, Melbourne, Victoria 8001, Australia

Tel. (03) 96884332 Fax. (03) 96885024 